\title{
PENERAPAN METODE DESIGN THINKING PADA MODEL PERANCANGAN UI/UX APLIKASI PENANGANAN LAPORAN KEHILANGAN DAN TEMUAN BARANG TERCECER
}

\author{
Aria Ar Razi ${ }^{1}$, Intan Rizky Mutiaz ${ }^{2}$ dan Pindi Setiawan ${ }^{3}$ \\ 1,2,3 Institut Teknologi Bandung \\ Jl. Ganesha No.10, Lb. Siliwangi, Coblong, Kota Bandung, Jawa Barat 40132 \\ tertawaria@gmail.com ${ }^{1}$, intanrm@yahoo.com², pindisp@yahoo.com ${ }^{3}$
}

\begin{abstract}
Abstrak: Penanganan terhadap kasus kehilangan dan temuan barang yang tercecer pada masyarakat urban di Indonesia dapat diselesaikan dengan perancangan aplikasi mobile pada smartphone. Minimnya informasi, keterbatasan sistem pengelolaan, serta belum adanya media teknologi alternatif menjadi sejumlah kendala dalam penanganan kasus kehilangan dan temuan barang tercecer. Dengan memanfaatkan kemajuan teknologi informasi dan komunikasi yang telah berkembang pesat melalui teknologi internet pada era digital, maka keterbatasan informasi tersebut dapat dikembangkan pada aplikasi mobile. Perancangan ini menggunakan metode design thinking, yang terdiri dari tahapan empathize, define, ideate, prototype dan test. Sehingga hasil dari perancangan ini memberikan rekomendasi berupa model UI/UX pada aplikasi mobile yang bernama "kembaliin", dengan mengidentifikasi permasalahan kebutuhan informasi yang terdapat pada penanganan kasus kehilangan dan temuan barang tercecer di tempat umum. Model perancangan aplikasi dirancang berdasarkan target pengguna dalam memfasilitasi kebutuhan pertukaran informasi untuk kasus kehilangan dan temuan barang tercecer bagi masyarakat urban. Model perancangan aplikasi ini berperan sebagai perantara dalam memfasilitasi kebutuhan pertukaran informasi antara pihak korban dan pihak penolong.
\end{abstract}

Kata kunci: aplikasi mobile, design thinking, kehilangan, temuan, UI/UX.

\begin{abstract}
Lost and found cases in Indonesian urban communities can be solved by the design of mobile applications on smartphone. The lack of information, the limitations of the management system, and the absence of alternative media have become a number of obstacles in handling the case of lost and found. By leveraging the advance of information and communication technology that has been growing rapidly through Internet nowadays, the limited information can be developed in mobile application. This design uses design thinking method which consists of empathize, define, ideate, prototype and test. Hence the result of this design provide recommendations in the form of UI/UX model on mobile application is called "kembaliin", by identifying the problem of information needs contained in the handling of lost and found cases at public places. The model of application is designed based on user target to facilitate the needs of information exchange on the case of lost and found for the urban community. This application model
\end{abstract}

Penulis adalah mahasiswa dan pengajar Program Studi Magister Desain FSRD ITB 
design acts as an intermediary in facilitating the needs of information exchange between the victims and the helper.

Keywords: mobile application, design thinking, lost, found, UI/UX

\section{PENDAHULUAN}

Pada era digital seperti saat ini, minimnya aksesibilitas informasi terhadap penanganan kasus kehilangan dan temuan barang tercecer atau lebih dikenal juga dengan istilah Lost and Found yang terjadi pada berbagai tempat umum di tengah kehidupan masyarakat urban di berbagai kota Indonesia masih menyisakan berbagai permasalahan. Hal ini cukup bertolak - belakang mengingat kemajuan teknologi dan informasi saat ini serta semakin mutakhirnya kecanggihan dari berbagai perangkat elektronik yang diproduksi oleh industri, seperti komputer dan berbagai perangkat mobile lainnya yang terhubung dengan internet, membuat istilah "dunia dalam genggaman" dapat dikatakan telah terwujud. Fenomena tersebut sesungguhnya persis seperti yang telah disampaikan oleh Thomas L. Friedman, sebagai the world is flat bahwa dunia semakin rata dan seharusnya setiap orang bisa mengakses informasi apapun dari sumber mana pun (Nasrullah, 2016: 1)

Ketika seseorang mengalami kasus kehilangan atau mendapati temuan barang tercecer, tindakan umum yang biasanya dilakukan sebagai sebuah upaya untuk mengembalikannya pada pemilik yang sah adalah dengan memanfaatkan sarana konvensional yang tersedia, yaitu mendatangi pusat informasi, menghubungi bagian security, bertanya pada orang sekitar yang berada pada tempat perkiraan kejadian, dan sebagainya. Namun, selain melalui upaya tersebut, saat ini khalayak juga mulai mencoba memanfaatkan sarana digital, contohnya berbagai konten dalam format digital yang mengandung narasi 
mengenai laporan kejadian kasus tersebut yang lazim dijumpai dan tampak bertebaran melalui sejumlah postingan pada berbagai social media.

Walaupun berbagai keunggulan pada sarana digital dirasakan pengguna, seperti jangkauan informasi yang lebih luas, kemudahan yang ditawarkan, dan efisiensi waktu. Namun, tetap saja masih banyak kekurangan, misalnya target tidak tepat sasaran, isu keamanan, serta keterbatasan layanan dari social media yang ada tidak dirancang untuk menangani kasus kehilangan dan temuan barang tercecer. Sehingga berdasarkan pemaparan tersebut, dibutuhkan sebuah media alternatif melalui keilmuan dalam bidang ilmu desain dengan membuat model perancangan aplikasi mobile yang dirancang khusus untuk mengatasi permasalahan kasus kehilangan dan temuan barang berharga yang tercecer di tempat umum. Hal ini didukung oleh pernyataan Daniel H Pink (2005: 65) yang mengungkapkan bahwa, di era konseptual dibutuhkan kemampuan yang berbeda dari era - era sebelumnya. Salah satu kemampuan yang penting adalah kemampuan desain.

Tujuan penelitian ini bermaksud membuat model perancangan UI/UX dengan melakukan inovasi dalam bentuk aplikasi mobile yang dirancang secara khusus untuk mengatasi permasalahan kasus kehilangan dan temuan barang tercecer di tempat umum.

\section{KAJIAN TEORI}

Secara umum aplikasi mobile (mobile application) adalah sebuah program aplikasi yang berjalan pada perangkat mobile misalnya smartphone maupun tablet $P C$ yang dirancang untuk menunjang aktivitas pengguna sehingga dapat mempermudah dan meningkatkan fleksibilitas pengguna. Dalam mengembangkan suatu aplikasi mobile menurut Griffith (2016: 17) dalam (Bangsawan, 2017: 21), terdapat berbagai pertimbangan mendasar terkait 
karakteristik serta jenis dari aplikasi yang akan dikembangkan. Pertimbangan tersebut akan mempengaruhi proses perancangan dan implementasi yang disebut dengan mobile solutions yang dibagi berdasarkan 3 kelompok aplikasi mobile. Pertama, Native Application Mobile yang merupakan aplikasi yang dikembangkan untuk satu platform tertentu menggunakan bahasa pemprograman spesifik yang sesuai dengan mobile OS yang digunakan. Kedua, Mobile Web Applications yang merupakan jenis aplikasi berbasis website/ web mobile yang diakses melauli browser penggunanya tidak dibatasi oleh sistem operasi apapun. Ketiga, Hybrid Mobile Application yang merupakan plikasi hybrid merupakan penggabungan dari aplikasi web dan native. Prinsip utama perancangan aplikasi ini menggunakan bahasa pemprograman mobile website, sedangkan beberapa fitur lainnya menggunakan native aplikasi mobile sesuai dengan mobile OS tujuannya.

User Experience (UX) merupakan seluruh aspek yang bekaitan dengan pengalam seorang pengguna dalam menggukan sebuah produk, seberapa mudah cara kerjanya untuk dipahami, bagaimana perasaan ketika menggunakan produk, dan bagaimana pengguna mencapai tujuannya melalui produk (Rahmasari \& Yanuarsari, 2017: 53). Sementara, salah satu bagian dari program yang bersentuhan dan berinteraksi langsung dengan user dinamakan User Interface (UI). (Blair-Early \& Zender, 2008: 85)

Kemudian dalam buku yang berjudul Hooked, Nir Eyal menjabarkan mengenai cara sebuah aplikasi membentuk kebiasaan pengguannya dan memaparkan secara terstruktur tentang empat langkah yang dirumuskan menjadi sebuah model siklus yang dikenal dengan nama Model Kait (Hooked Model). Empat tahap dalam Model Kait tersebut adalah sebagai berikut: pemicu (triggers) adalah actuator perilaku-tombol yang menyalakan mesin, tindakan (actions) adalah Keputusan pengguna untuk bertindak setelah termotivasi untuk meggunakan fitur yang ditawarkan oleh aplikasi, imbalan bervariasi (rewards) 
Pada tahap ini imbalan diberikan sebagai bentuk apresiasi terhadap pengguna, dan investasi (investment) muncul setelah tahap imbalan bervariasi dan merupakan sesuatu yang dimiliki oleh pengguna melalui sebuah upaya yang diberikan menggunakan produk (Eyal, 2016: 4).

\section{METODE PERANCANGAN}

Dalam penelitian ini, metode yang digunakan dalam melakukan perancangan adalah metode "design thinking", metode ini dikenal sebagai suatu proses berpikir komprehensif yang berkonsentrasi untuk menciptakan solusi yang diawali dengan proses empati terhadap suatu kebutuhan tertentu yang berpusat pada manusia (human centered) menuju suatu inovasi berkelanjutan berdasarkan kebutuhan penggunanya. Lebih lanjut lagi dipaparkan bahwa, awalnya terdapat 3 tahapan yang terdiri dari inspiration yaitu kebutuhan atau masalah yang memotivasi pencarian suatu solusi atau inovasi, ideation yaitu proses menghasilkan gagasan, pengembangan dan pengujian gagasan, dan yang terakhir implementation yaitu finalisasi peneranan ke pengguna. Dalam perkembangannya, ketiga tahapan tersebut berkembang menjadi 5 tahapan yang pada dasarnya tidak berbeda jauh namun terdapat penekanan pada bagian tertentu sehingga menghasilkan prosedur yang lebih terperinci.

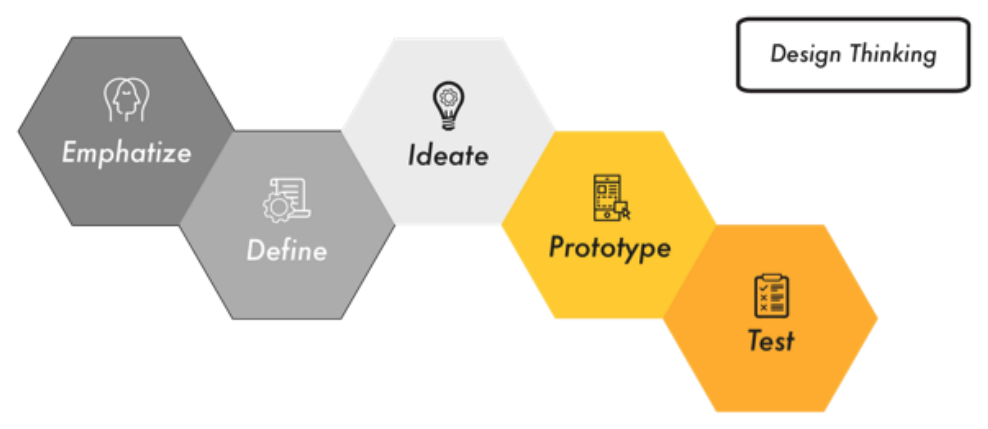

Gambar 1. Diagram tahapan dalam metode design thinking

Sumber: Plattner, 2010 
Tahapan yang pertama ialah Emphatize (Empati) yang dianggap sebagai inti dari proses perancangan yang berpusat pada manusia (human centered design), metode ini berupaya untuk memahami pengguna dalam konteks produk yang dirancang, dengan melakukan observasi, wawancara, dan menggabungkan observasi dan wawancara dengan terlebih dahulu diberikan suatu skenario. Tahap kedua ialah Define (Penetapan) yang merupakan proses menganalisis dan memahami berbagai wawasan yang telah diperoleh melalui empati, dengan tujuan untuk menentukan pernyataan masalah sebagai point of view atau perhatian utama pada penelitian. Tahapan ketiga ialah Ideate (Ide) yang merupakan proses transisi dari rumusan masalah menuju penyelesaian masalah, adapun dalam proses ideate ini akan berkonsentrasi untuk menghasilkan gagasan atau ide sebagai landasan dalam membuat prototipe rancangan yang akan dibuat.

Keempat ialah Prototype (Prototipe) dikenal sebagai rancangan awal suatu produk yang akan dibuat, untuk mendeteksi kesalahan sejak dini dan memperoleh berbagai kemungkinan baru. Dalam penerapannya, rancangan awal yang dibuat akan diujicoba kepada pengguna untuk memperoleh respon dan feedback yang sesuai untuk menyempurnakan rancangan. Terakhir ialah tahapan Test (Uji coba) atau pengujian dilakukan untuk mengumpulkan berbagai feedback pengguna dari berbagai rancangan akhir yang telah dirumuskan dalam proses prototipe sebelumnya. Proses ini merupakan tahap akhir namun bersifat life cycle sehingga memungkinkan perulangan dan kembali pada tahap perancangan sebelumnya apabila terdapat kesalahan (Brown \& Katz, 2009: 2). 


\section{HASIL DAN DISKUSI}

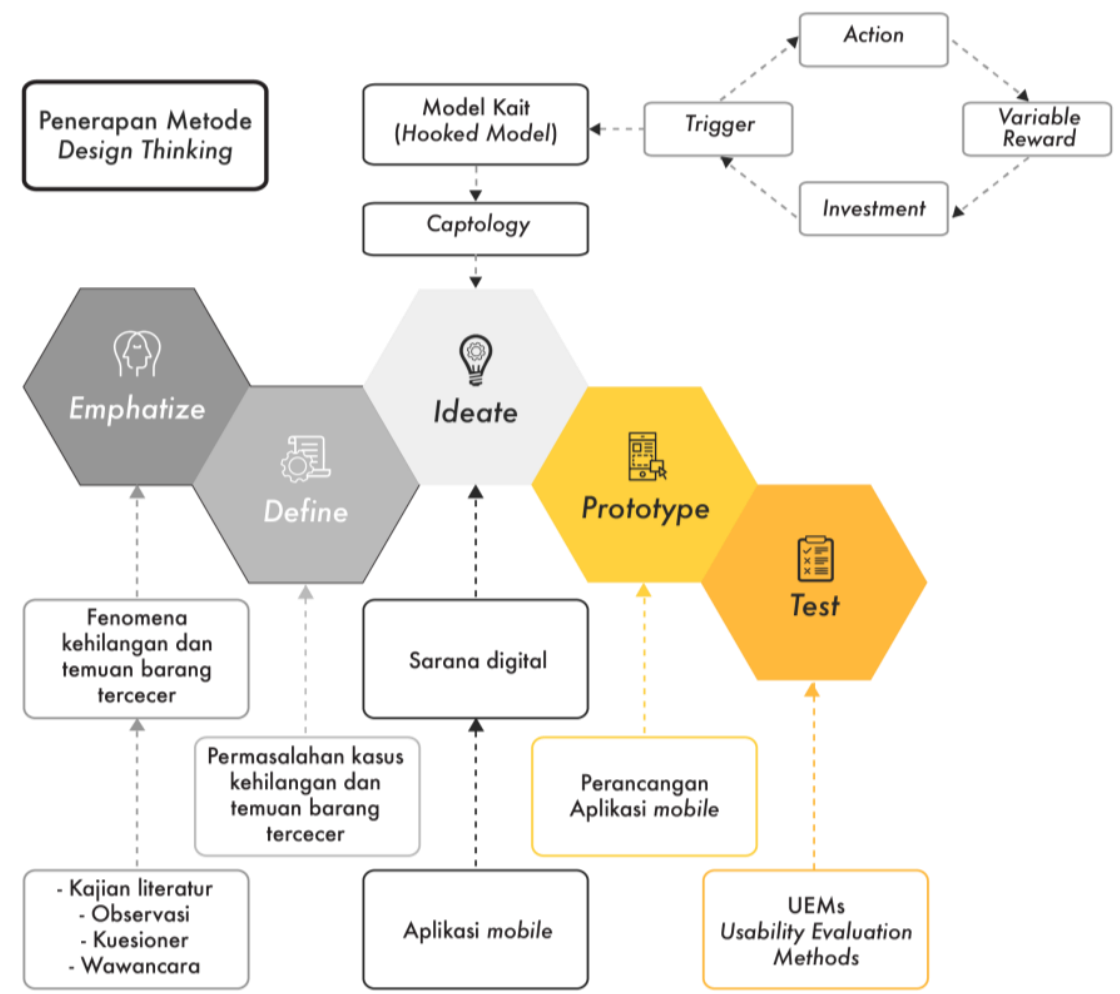

Gambar 2. Diagram hubungan antara teori yang digunakan dalam metode perancangan

Sumber: Razi, 2018

Berdasarkan metode design thinking, penulis mencoba memaparkannya dalam kerangka alur metode sehingga didapatkan hasil perancangan yang dapat mengatasi permasalahan utama dalam penelitian ini.

\section{Empathize}

Tahapan emphatize ini mencakup observasi, wawancara dan penyebaran kuesioner kepada calon pengguna guna mendapatkan insight fokus penelitian mengenai kasus kehilangan dan temuan barang tercecer. Observasi dilakukan pada bebebrapa lingkungan tempat umum dan social media, sementara wawancara dilakukan dengan beberapa pihak seperti pihak keamanan (security) 
Bandara Husein Sastraegara, pusat perbelanjaan Paris Van Java, pengelolaan di lingkungan kampus ITB, dan seorang Liaison Officer penyelenggara event. Kemudian penyebaran kuesioner yang dilakukan kepada 33 orang responden untuk pembuktian asumsi dan memetakan permasalahan. Sehingga dapat dirumuskan hal yang menjadi perhatian utama dalam penelitan yang pertama ialah khalayak masih belum menemukan media yang paling efektif dalam mengelola kasus kehilangan dan temuan barang tercecer di tempat umum, sehingga masih dibutuhkan berbagai sarana alternatif lain dalam menangani kasus ini. Kedua, kendala yang dialami dalam mengurus barang hilang atau temuan barang tercecer mempengaruhi khalayak menjadi urung dalam menangani kasus.

Kemudian yang ketiga, kendala yang didapatkan dari kasus kehilangan dan temuan barang tercecer antara lain ialah; ketiadaan identitas, keterbatasan sarana pelaporan, ketiadaan pihak berwenang di sekitar, adanya oknum yang memanfaatkan situasi, kurangnya tingkat kepedulian khalayak, keterbatasn waktu, target jangkauan yang informasi tidak menemui sasarannya. Dan keterbatasan layanan dari social media yang ada. Keempat, teknologi seharusnya dapat menjadi solusi dan dapat mengubah kehidupan masyarakat dan menempatkan dirinya berdasarkan fungsi sebagai alat, sebuah media, atapun sebagai pelaku sosial.

Kelima, kemungkinan tindakan tidak akan dilakukan apabila melakukannya lebih sulit daripada memikirkannya, semakin banyak usaha yang diperlukan baik dari segi fisik ataupun mental yang harus dikeluarkan untuk melaksanakan tindakan, kemungkinan tindakan yang terjadi malah semakin kecil. Kemudian yang keenam ialah khalayak saat ini mulai melirik penggunaan sarana digital melalui social media yang digunakan sebagai alternatif upaya dalam menyelesaikan kasus kehilangan dan temuan. Terakhir ialah isu keamanan merupakan isu yang menjadi perhatian utama dalam kasus pengelolaan laporan kehilangan dan temuan barang tercecer secara digital. 


\section{Define}

Berdasarkan proses define didapatkan bahwa inti permasalahan utama yang dapat disimpulkan dari hasil proses empati adalah minimnya sarana informasi yang dapat mengelola laporan kehilangan dan temuan barang tercecer. Sehingga solusinya adalah menghadirkan media alternatif dalam bentuk aplikasi mobile yang dirancang khusus sesuai target pengguna yang mampu memfasilitasi kebutuhan pertukaran informasi dengan memanfaatkan tekonologi internet. Lebih lanjut lagi, berdasarkan data yang diperoleh, target pengguna yang ditentukan berusia 19 - 34 tahun dan berasal dari kalangan kaum urban dan telah terbiasa dalam menggunakan smartphone dengan karakteristik target pengguna terbiasa menggunakan social media. Menurut data yang diperoleh melalui APJII (Asosiasi Penyelenggara Jasa Internet Indonesia) dalam laporan berjudul penetrasi \& perilaku pengguna internet Indonesia tahun 2017. Pengguna dari kalangan tersebut merupakan presentase terbesar pengguna internet di Indonesia sebanyak 49,52\% (APJII, 2017).

\section{Ideate}

Ide yang akan dibuat dari tahapan define sebelumnya adalah mengenai cara menghasilkan aplikasi mobile yang mampu menjawab permasalahan kasus kehilangan tan temuan barang tercecer di tempat umum. Penerapan konsep komunikasi persuasif dalam perancangan ini akan menjadi sebuah strategi untuk mempengaruhi sikap dan perilaku calon pengguna untuk beralih melaporkan kasus kehilangan dan temuan barang tercecer ke media online dengan melakukan penerapan model kait (hook model). Melalui strategi hook model ini diharapkan akan membentuk kebiasaan baru para calon pengguna. 


\section{Prototype}

Dari proses yang dilalui dalam tahapan empati sebelumnya, didapatkan hasil kesimpulan mengenai berbagai alur kebiasaan yang dilakukan oleh khalayak saaat mengalami kasus kehilangan atau menemukan barang tercecer. Alur tersebut kemudian dirumuskan kembali hingga menjadi alur yang digunakan dan dijadikan acuan dalam merancang fitur yang ada dalam aplikasi mobile ini. Berikut adalah alur aplikasi yang dihasilkan, berdasarkan proses empati:

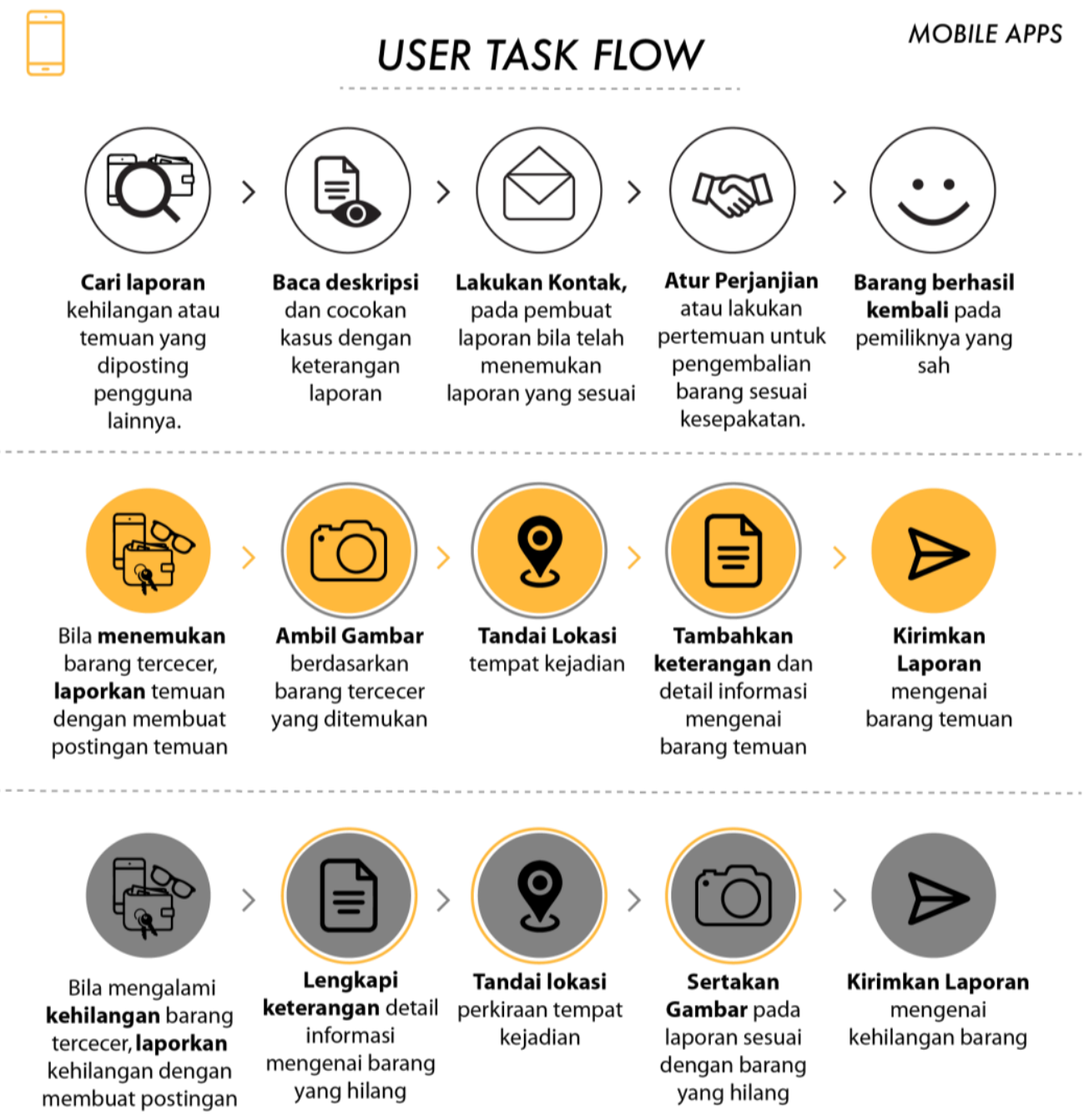

Gambar 3. User Task Flow aplikasi mobile

Sumber: Razi, 2018 
Kemudian, salah satu strategi terstruktur lainnya yang dilakukan ialah melalui strategi komunikasi. Untuk membuat aplikasi ini dikenali oleh khalayak dan membuatnya mudah diingat, aplikasi ini diberi nama "kembaliin". Kata ini berasal dari kata "kembali" yang menurut Kamus Besar Bahasa Indonesia (KBBI) memiliki arti kembali ke tempat atau keadaan semula semula. Kata "kembaliin" sendiri merupakan kata tutur yang tidak baku namun sering digunakan dalam percakapan sehari - hari yang merujuk pada kata "mengembalikan" sebagai sebuah aktifitas atau kata "kembalikan" yang merupakan kata perintah. Hal ini sesuai dengan kasus kehilangan dan temuan barang tercecer, yang meminta orang lain untuk mengembalikan barang tercecer miliknya.
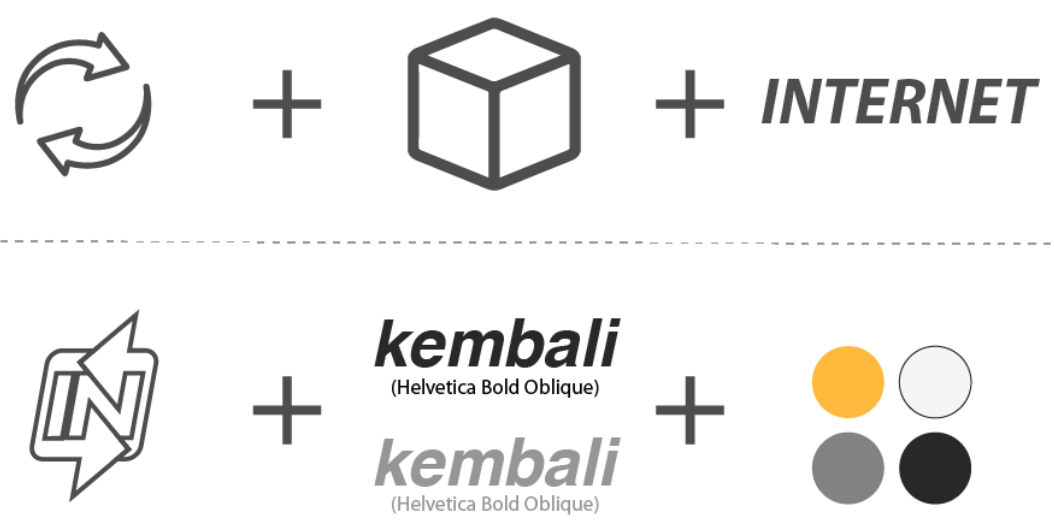

\section{kembali[4}

Gambar 4 Breakdown logo aplikasi mobile "kembaliin"

Sumber: Razi, 2018

Logo aplikasi "kembaliin" merupakan hasil gabungan dan penyederhanaan dari 3 tanda yang merepresentasikan aplikasi, yaitu gabungan dua buah bentuk tanda panah dua arah yang menggambarkan bentuk sebuah siklus, bentuk kotak, 
serta kata "IN". Makna yang diusung oleh tanda panah ini ialah, satu panah berwarna abu - abu yang mewakili barang tercecer yang hilang, sementara panah lainnya yang berwarna kuning mewakili barang tercecer yang ditemukan. Kedua panah tersebut membentuk siklus yang merepresentasikan barang hilang dan temuan kembali ke awal atau kepada pemiliknya yang sah, kemudian bentuk dasar kotak yang menggambarkan barang tercecer, serta kata "IN". yang mewakili internet. Selain logogram tersebut, logo aplikasi "kembaliin" juga terdiri dari logotype bertuliskan kata "kembali".

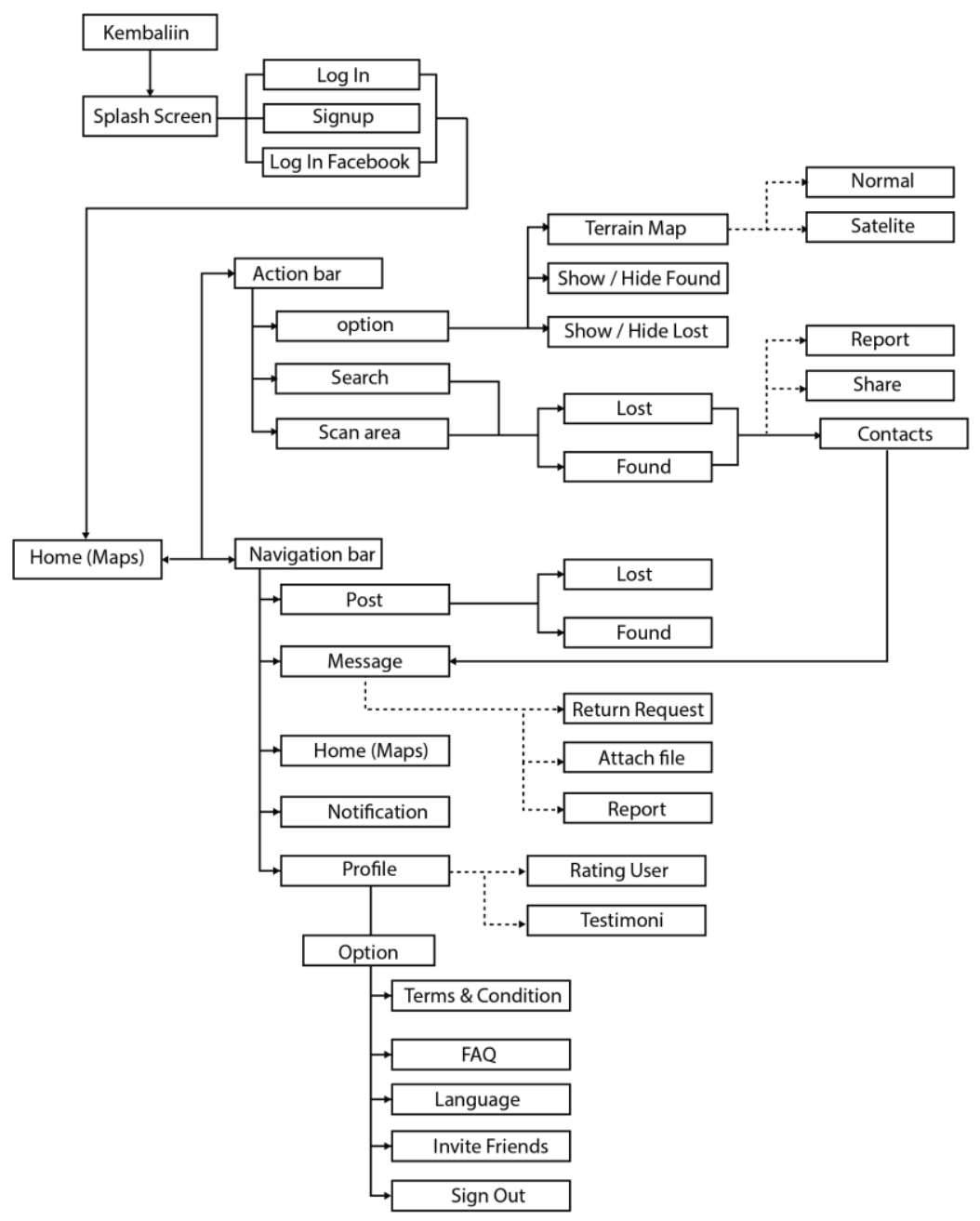

Gambar 5 Flow chart dari aplikasi "kembaliin"

Sumber: Razi, 2018 
Konsep perancangan aplikasi mobile dituangkan dalam bentuk perancangan alur operasional aplikasi "kembaliin". Alur operasional aplikasi "kembaliin" akan dimulai pada saat pengguna menekan tombol ikon aplikasi yang telah terpasang pada smartphone yang digunakan oleh pengguna. Alur operasional aplikasi "kembaliin" dapat dilihat pada gambar 5, dimana pada alur operasional aplikasi dijelaskan bahwa terdapat proses, yaitu splash screen, registrasi sebelum masuk ke halaman utama.

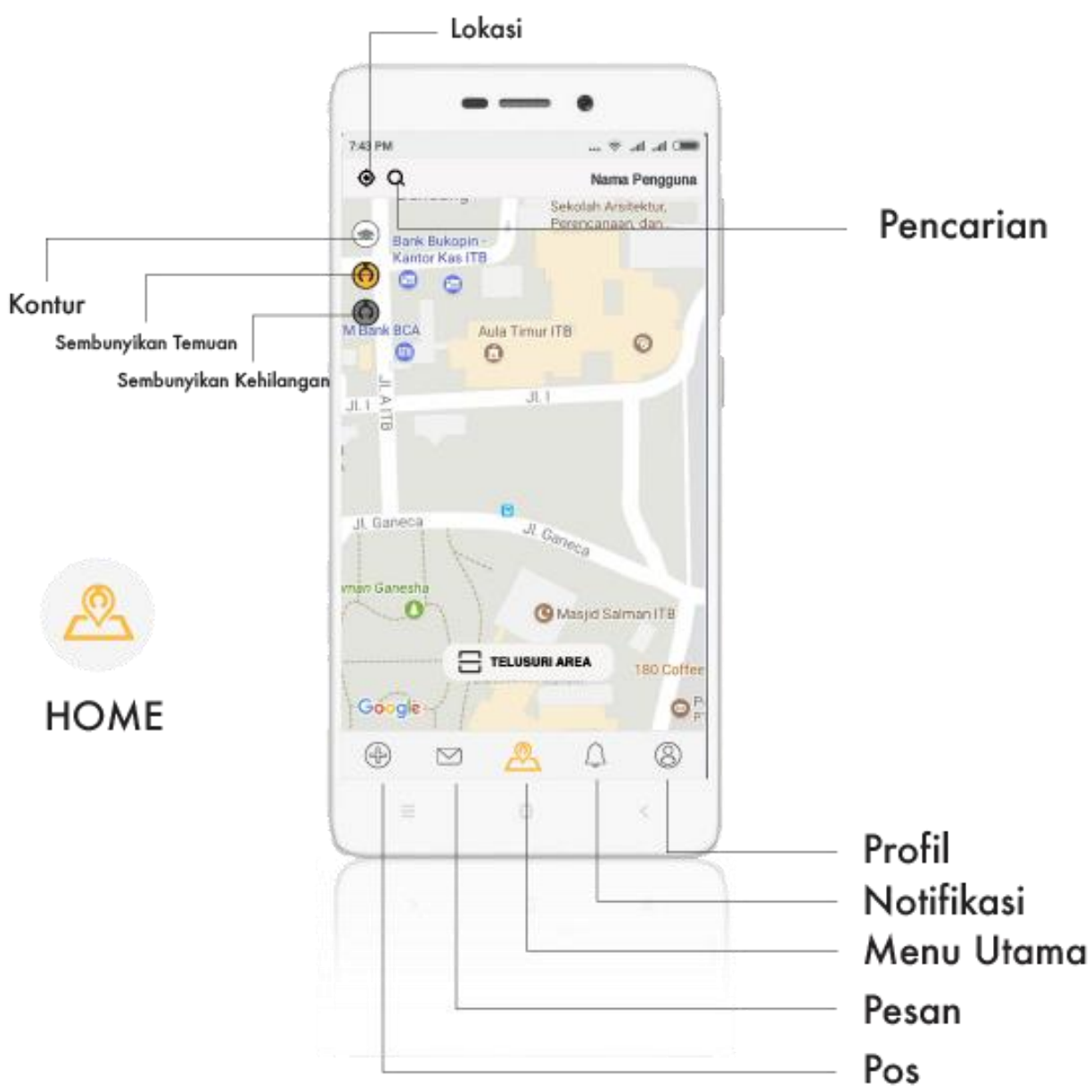

Gambar 6 Tampilan halaman menu utama (home) pada aplikasi mobile "Kembaliin" Sumber: Razi, 2018 
Halaman menu utama (home) pada aplikasi "kembaliin" merupakan wajah bagi "kembaliin". Pada halaman tersebut, terdapat 5 buah menu utama pada navigation bar yaitu posting (post), pesan (message), menu utama (home), notifikasi (notification) dan profil (profile). Pada halaman menu utama "kembaliin", tampilan pertama yang ditampilkan adalah peta (maps) yang berasal dari sistem GPS dari GoogleMaps untuk melakukan fitur penelusuran wilayah dan pencarian terhadap laporan kehilangan dan temuan yang telah dilaporkan. Pengguna dapat melakukan pencarian terhadap laporan yang telah terbit melalui fitur telusuri wilayah (scan this area) untuk menampilkan laporan yang terdapat pada sekitar wiayah tersebut. Kemudian bila pengguna tak ingin menggunakan fitur ini dan ingin melakukan pencarian lebih lanjut mengenai laporan yang terdapat pada aplikasi ini dengan menggunakan kata kunci, pengguna dapat melakukan pencarian melalui action bar dengan ikon berbentuk kaca pembesar (spotlight) yang terdapat pada bagian atas aplikasi.

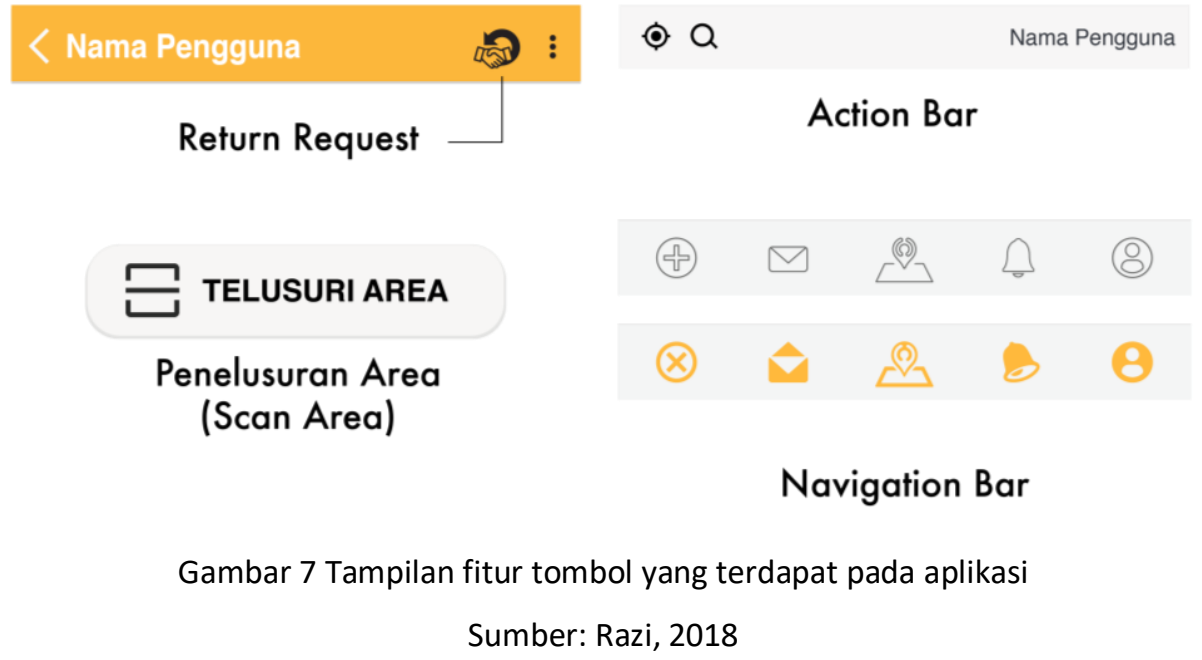

Setiap postingan yang ditampilkan berdasarkan posisi peta, dapat dipilih oleh pengguna. Melalui postingan tersebut, pengguna dapat melihat barang tercecer yang dilaporkan hilang atau telah ditemukan, kemudian melihat keterangan yang dimiliki dari laporan tersebut. Apabila pengguna menemukan 
kesesuaian ciri, deskripsi dan keterangan yang disampaikan pada postingan, maka pengguna dapat melakukan kontak terhadap pengguna lain yang memposting postingan tersebut dengan memilih tombol kontak (contact) yang tersedia pada bagian bawah keterangan. Ketika pengguna memutuskan memilih tombol kontak, maka pengguna diarahkan langsung oleh aplikasi ke halaman percakapan yang terdapat pada menu pesan (message).

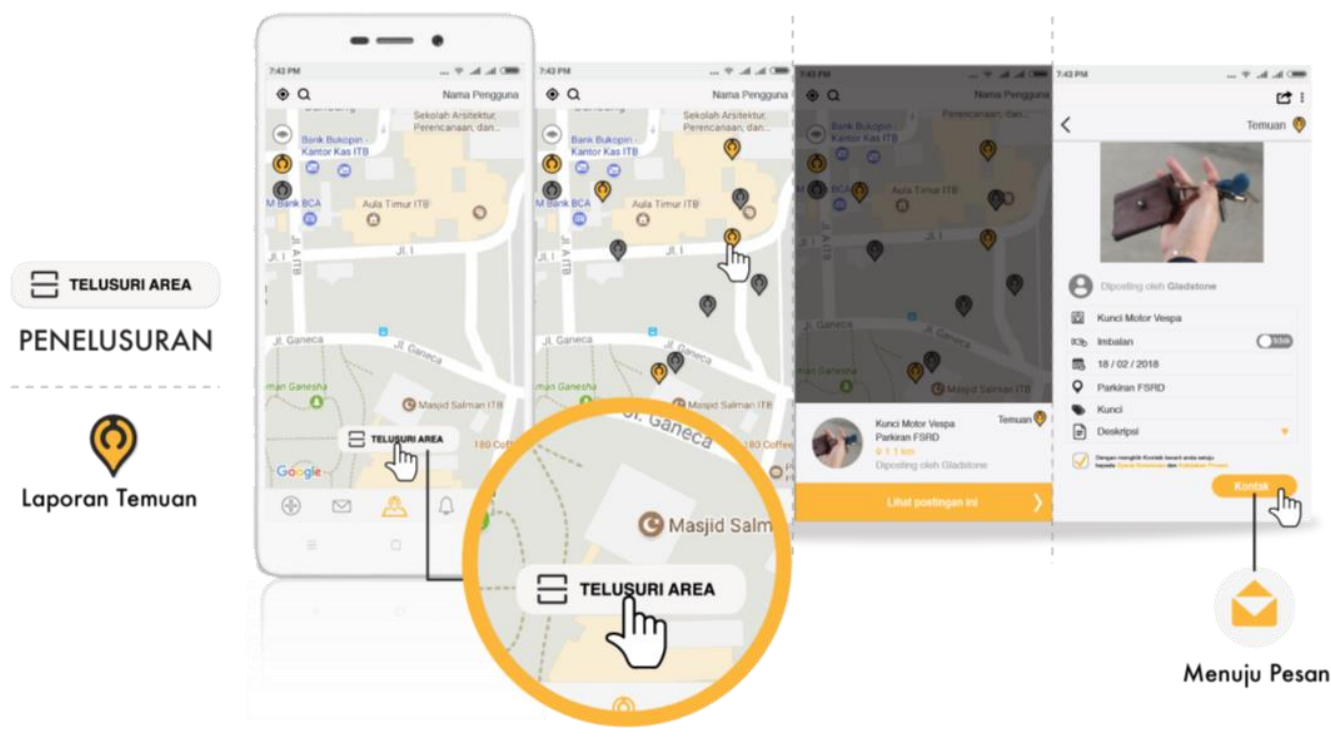

Gambar 8 Tampilan halaman penelurusan wilayah (scan area) laporan temuan Sumber: Razi, 2018

Sementara halaman menu pesan, merupakan halaman menu yang disediakan untuk memfasilitasi komunikasi pengguna dengan pengguna lainnya. Pada halaman menu inilah hubungan komunikasi antar pengguna dapat terjadi, selain itu pada halaman ini juga pengguna dapat melakukan persetujuan transaksi melalui fitur permintaan pengembalian (return request), persetujuan (approval) dan verifikasi (verification) melalui anjuran yang telah ditetapkan oleh Kembaliin. Selain fitur utama pencarian, fitur yang tak kalah pentingnya pada aplikasi "kembaliin" adalah fitur untuk membuat atau menambahkan postingan mengenai 
laporan kehilangan (lost) dan temuan (found) itu sendiri. Untuk membuat postingan laporan, pengguna juga akan dimudahkan dengan hanya melalui 3 langkah saja pada aplikasi.

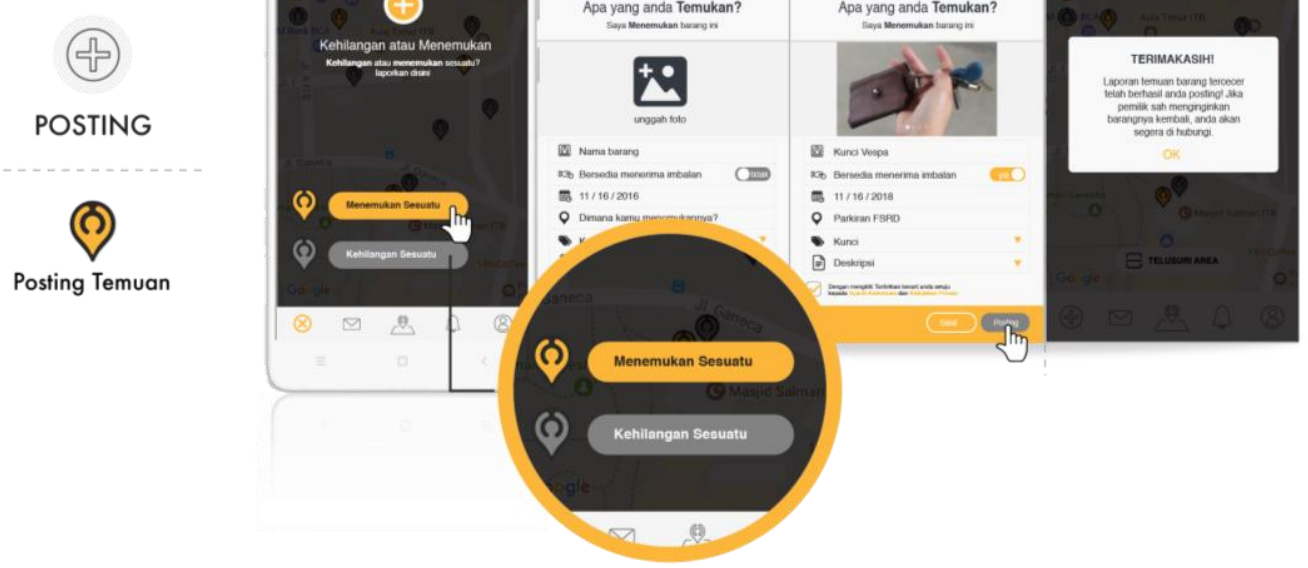

Gambar 9 Tampilan halaman posting (post) pada aplikasi Sumber: Razi, 2018

Test

Tahapan terakhir pada metode design thinking ini penulis melakukan uji coba produk yang dihasilkan pada tahapan prototype sebelumnya. Pengujian aplikasi "kembaliin" ini dilakukan dengan melalui dua tahap, yaitu dengan ujicoba digital prototyping dan kuesioner. Meskipun target pengguna, menilai bahwa secara keseluruhan aplikasi "kembaliin" sebagai aplikasi yang sangat bermanfaat dan telah sesuai dengan kebutuhan mereka, namun tetap memiliki beberapa kendala untuk dijadikan masukan dan perbaikan. Pertama, pengguna membutuhkan waktu sebelum membiasakan diri menggunakan aplikasi dan mengerti fitur, ikon serta tombol yang dimiliki aplikasi. Kedua, menurut pengguna jarak tombol yang belum sesuai dengan ibu jari, serta ukuran tombol yang masih dirasa belum menemukan format terbaiknya. Terakhir Beberapa pengguna 
mengalami kesulitan dalam membaca tulisan dan deskripsi yang terdapat pada aplikasi.

\section{KESIMPULAN}

Meskipun berada pada era digital, ternyata penanganan terhadap permasalahan kasus kehilangan dan temuan barang tercecer masih belum menemukan solusi terbaiknya. Fakta yang diperoleh melalui jajak pendapat yang merupakan hasil temuan dalam penelitian ini, memperlihatkan bahwa khalayak masih belum menemukan media yang paling efektif dalam penanganan terhadap kasus kehilangan dan temuan barang tercecer di tempat umum. Khalayak juga sangat setuju dan tertarik apabila tersedia aplikasi mobile yang mampu menangani permasalahan tersebut.

Oleh sebab itu, melalui penerapan metode design thinking dalam perancangannya, aplikasi mobile "kembaliin" berupaya menjawab berbagai tantangan atas permasalahan tersebut. Melalui karakteristik dan berbagai fitur yang dimilikinya, aplikasi "kembaliin" berbasis Maps (peta) ini dapat menjadi wadah dalam melakukan pencarian laporan kehilangan dan temuan barang tercecer melalui fitur pencarian (search) melalui kata kunci atau fitur penelusuran area (scan this area) yang membuat pengguna dapat menelusuri wilayah dalam peta secara online untuk menemukan laporan dengan cara yang lebih menyenangkan, jangkauan yang lebih luas dan tepat sasaran.

Selain pencarian, tentu saja yang tidak kalah pentingnya adalah aplikasi dapat digunakan sebagai media yang mampu melaporkan kasus kehilangan dan temuan benda tercecer di tempat umum melalui fitur posting (post) yang dapat menampung kebutuhan utama pengguna mempercepat penanganan. Aplikasi ini juga sekaligus berperan sebagai perantara yang dapat menghubungkan kedua pihak melalui fitur pesan (message) yang memungkinkan terjadinya percakapan 
dan kesepakatan antar pengguna, selalu memberikan kabar terbaru melalui fitur notifikasi (notification) yang membuat pengguna tidak akan melewatkan aktivitas terbaru yang berkaitan dengan pengguna, serta akan menjamin keamanan privasi penggunanya melalui fitur permintaan pengembalian (return request) saat pengguna hendak mengklaim barang tercecer dan fitur verifikasi (verification) antar pengguna yang membuat kedua pihak merasa aman.

Sehingga dapat disimpulkan secara keseluruhan bahwa aplikasi "kembaliin" merupakan model perancangan media berbasis teknologi yang dirancang secara khusus sesuai target pengguna untuk mengatasi permasalahaan kasus kehilangan dan temuan barang tercecer di tempat umum. Namun untuk mewujudkan keberhasilannya, aplikasi "kembaliin" sendiri hanya dapat dicapai dengan adanya dukungan partisipasi khalayak dalam memegang kejujuran dan menjunjung tinggi budaya saling tolong menolong dalam masyarakat.

Pada perancangan ini, hasil yang didapatkan adalah sebuah model perancangan dalam bentuk aplikasi mobile pada smartphone yang merupakan Native Mobile Aplication, sehingga pada penelitian berikutnya, apabila ingin menyempurnakan perancangan ini dapat mempertimbangkan untuk melakuan perancangan dalam bentuk aplikasi Hybrid mobile dimana aplikasi akan bersifat multi platform yang bisa terdiri dari gabungan perancangan web, web mobile dan native aplikasi mobile sendiri yang terintegrasi satu sama lainnya melalui suatu peneltian tersendiri. Kemudian Dari segi teknologi, perancangan aplikasi ini berkonsentrasi pada perangkat smartphone dengan sistem operasi Android. Sehingga penelitian selanjutnya dapat mempertimbangkan untuk mengembangkannya pada perangkat lain dengan sistem operasi yang berbeda seperti iOS. 


\section{DAFTAR PUSTAKA}

APJIII, 2017. Infografis Penetrasi \& Perilaku Pengguna Internet Indonesia Survey 2017, https://apjii.or.id/survei2017/. (20 Februari 2018)

Bangsawan, M., 2017. Perancangan Aplikasi "Kalima" sebagai Layanan Informasi Kuliner Kaki Lima Kota Bandung, Tesis Program Magister, Bandung: Institut Teknologi Bandung

Blair-Early, A. dan Zender, M., 2008. User Interface Design Principles for Interaction Design. Design Issues, Volume 24 Number 3, hal 85, https://www.mitpressjournals.org/doi/abs/10.1162/desi.2008.24.3.85?jou rnalCode=desi. (12 Agustus 2018)

Brown, T. dan Katz, B., 2009. Change by Design. New York: Harper Collins

Eyal, N., 2016. Hooked: Bagaimana Aplikasi Membentuk Kebiasaan Kita, Jakarta: Kepustakaan Populer Gramedia

Griffith, C., 2016. Mobile App Development with Ionic 2, USA: O'Reilly Media

Nasrullah, R., 2016. Media Sosial, Perspektif komunilasi, budaya dan sosisoteknologi, Simbiosa Rekatama Media, Bandung

Pink, D. H., 2005. A Whole New Mind: berpindah dari jaman informasi menuju konsep konseptual, Jakarta: Penerbit Dinastindo

Plattner, H., 2010. An Introduction to Design Thinking Process Guide, Stanford: Institute of Design at Stanford

Rahmasari, E. A. dan Yanuarsari, D. H., 2017. Kajian Usability dalam Konsep Dasar User Experience pada Game "ABC KIDS-TRACING AND PHONICS" Sebagai Media Edukasi Universal untuk Anak. Jurnal Demandia, Vol. 02 No, 01, hal 52, http://journals.telkomuniversity.ac.id/demandia/article/view/770. (12 Agustus 2018) 